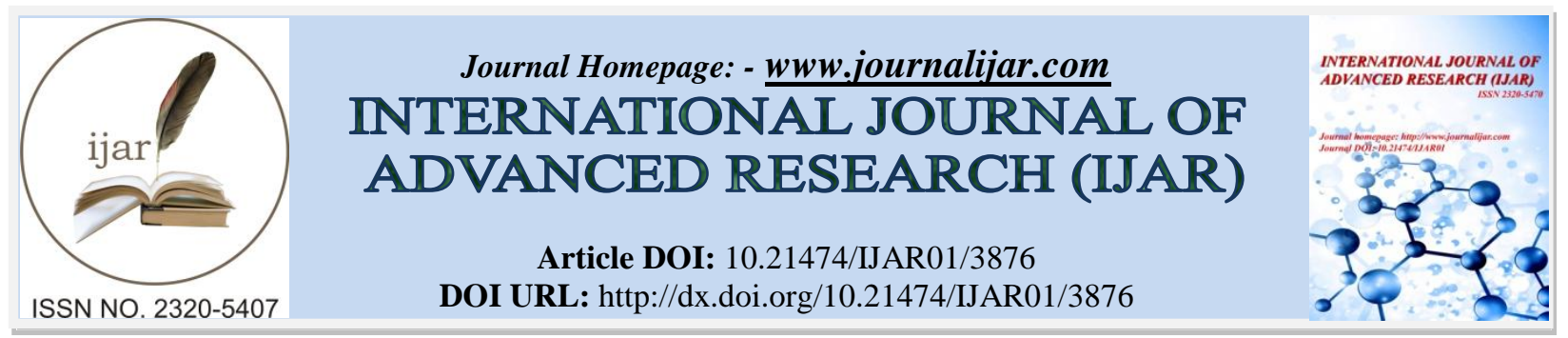

RESEARCH ARTICLE

\title{
TESTING OF HIGH STRENGTH STEEL-CONCRETE COMPOSITE STUB COLUMNS UNDER UNIAXIAL LOAD.
}

Khushbu Shah ${ }^{1}$ and Dr. D. R. Panchal ${ }^{2}$.

1. M.E. Civil Research Scholar, Department of Applied Mechanics, FTE, M S University of Baroda, Vadodara, Gujarat, india.

2. Assistant Professor, Department of Applied Mechanics, FTE, M S University of Baroda, Vadodara, Gujarat, India.

\section{Manuscript Info}

[.........................

Manuscript History

Received: 14 February 2017

Final Accepted: 10 March 2017

Published: April 2017

Key words:-

Axial Compressive Load, CFST Stub

Columns, Concrete Grade, High

Strength Steel, Local Buckling, Vertical

Deflection.

\section{Abstract}

Here, Paper represent experimental study about the steel-concrete composite stub columns under Uni-axial load. Here, two types of CFST columns were used of shape circular and square hollow steel tubes with high strength steel (Grade-310) and is in filled with three different grades of concrete like M20, M30 and M40. Specimen that have been studied of eighteen square samples of dimension $91.5 \mathrm{~mm} * 91.5 \mathrm{~mm}$ *300 mm and eighteen circular samples of dimension $114.31 \mathrm{~mm} * 300$ $\mathrm{mm}$ and thickness of the specimen is used of $4.5 \mathrm{~mm}$. A load applied on columns was axially compressive load and vertical displacement measured. The effects of grade of concrete and composite action between the steel tube and the concrete core on axial load capacity are studied and graphs of axial load v/s vertical deflection (axial shortening curves) are plotted.

Copy Right, IJAR, 2017, All rights reserved.

\section{Introduction:-}

The term composite structure is defined by the structure which consist more than one material combined together by bond or friction.

Composite members combines both steel and concrete means that is beneficial qualities to both of the materials. Steel members have the advantages of high tensile strength and ductility, while concrete members have the advantages of high compressive strength and fire resistance. There are two types of CFST columns. One is steel sections encased with concrete and other is concrete filled steel columns.

In recent trend, building design emphasizes on enhancing flexibility of the floor space by reducing cross section size of column and more usable floor space area by using composite columns.

By using smaller section size of column enhancing compressive strength gives more strength of column. Higher grade of concrete gives higher strength but it leads to brittle failure. This would be prevented by reducing space of stirrup for higher ductility. By using composite columns, there is no need to provide additional formwork because of the hollow steel tubes around the concrete.

Corresponding Author: - Khushbu Shah.

Address: - M.E. Civil Research Scholar, Department of Applied Mechanics, FTE, M S University of

Baroda, Vadodara, Gujarat, India. 
Table -1: The Material properties of the Steel-tubes

\begin{tabular}{|c|c|c|c|c|c|}
\hline \multirow{3}{*}{ Section Type } & \multirow{2}{*}{ Grade } & \multicolumn{4}{|c|}{ Mechanical Properties } \\
\cline { 3 - 6 } & & YST & UTS & \multicolumn{2}{c|}{$\%$ of Elongation } \\
\cline { 3 - 6 } & $(\mathrm{MPa})$ & $(\mathrm{MPa})$ & $<25.4 \mathrm{~mm}$ & $>25.4 \mathrm{~mm}$ \\
\hline \multirow{3}{*}{ RHS/SHS IS : 4923 } & YST 210 & 210 & 330 & 12 & 20 \\
\cline { 2 - 6 } & YST 240 & 240 & 410 & 10 & 15 \\
\cline { 2 - 6 } & YST 310 & 310 & 450 & 8 & 10 \\
\hline \multirow{3}{*}{ CHS IS : 1161 } & YST 210 & 210 & 330 & 12 & 20 \\
\cline { 2 - 6 } & YST 240 & 240 & 410 & 12 & 17 \\
\cline { 2 - 6 } & YST 310 & 310 & 450 & 12 & 14 \\
\hline
\end{tabular}

According to one research paper BurakEvirgen, KivancTaskin, (2014), investigated the compressive behaviour of CFST section considering various cross-sectional shapes like circular, hexagonal, rectangular and square. Experimental study was carried out by varying B/t (Breadth to thickness) ratio and grades of concrete. The obtained results of experimental study were compared with ABAQUS software. In this study, researchers observed that the concrete core of CFST resists the inward buckling of steel tube and steel tube provides better confinement to concrete core which results increase in the strength of CFST section. The study also shows that the ductility of the circular CSFT section is more than hexagonal, rectangular and square CFST sections.

E K Mohanraj; S Kandasamy; R Malathy (2008) observed that in long columns, general buckling and in short columns, crushing of concrete. The performance of CFST under sustained loads is different from ordinary reinforced concrete columns. In RCC columns, concrete experiences contraction as it sets during its early age. Earlier construction was small in size with respect to present construction. But, Now a days, the development of high rise buildings and the need to provide more rigid structural systems to sustain severe lateral loads due to seismic and wind conditions lead to the necessity for mixed steel and concrete systems or say composite structures.

Fy310 possesses high yield strength $(310 \mathrm{Mpa}) \&$ high ultimate strength $(450 \mathrm{Mpa})$. I.e. it is a high strength material against axial, bending and shear stresses compare to Fy210 \& Fy240 grade of steel. Grade 310 has combining excellent high temperature properties with good ductility and weldability, is designed for high temperature service. It is also used for intermittent service at temperatures up to $1040^{\circ} \mathrm{C}$. Here, we have compared the difference of the axial load capacity of the circular and square CFST columns of high grade of steel for different grades (M20, M30 \& M40) of concrete. We have found out also the effect on strength using the different grades of concrete infilled in the hollow steel tubes. Area of cross-section and moment of inertia of both types of steel tubes have same.

\section{Experimental Program:-}

The columns were tested for static axial load by using Compression Testing Machine (200T) as shown in Fig.1-2. Complete test setup used is shown in Fig.1-2. Two different type shapes (circular and square) of column with three different grades of concrete. i.e. M20, M30 and M40 were tested. Total 36 numbers of columns were tested. Column was fixed at both ends by plate and compressive load applied on it. Digital dial gauge was set up near the column's upper surface for measurement of vertical displacement. A pre-load of about $5 \mathrm{kN}$ was applied to hold the specimen upright. Deformation readings were recorded at the each interval of $50 \mathrm{kN}$ loading. 


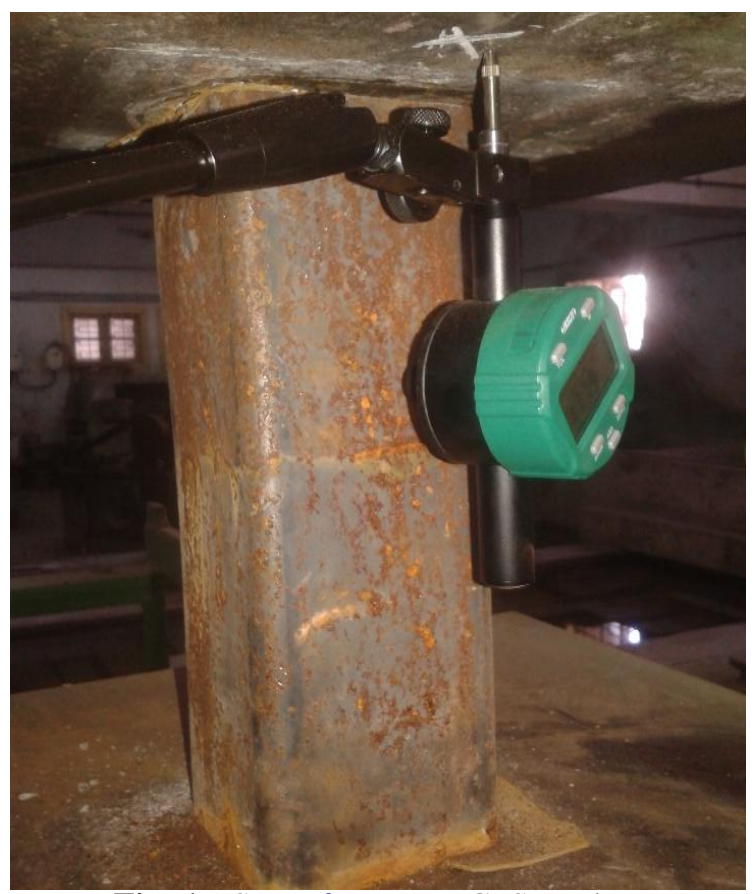

Fig: 1:- Setup for square CFST column

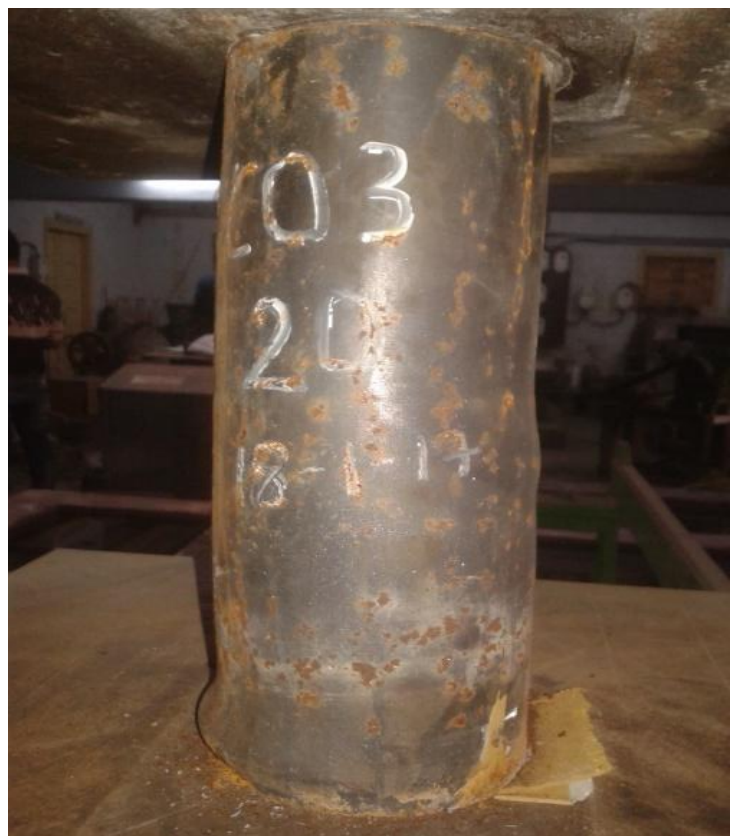

Fig: 2:- Setup for circular CFST column.

Table 2:- Concrete strengths

\begin{tabular}{|c|c|}
\hline Grade of concrete & $\mathrm{F}_{\mathrm{ck}}\left(\mathrm{N} / \mathrm{mm}^{2}\right)^{*}$ \\
\hline M20 & 20 \\
\hline M30 & 31 \\
\hline M40 & 40 \\
\hline
\end{tabular}

*indicates average design strength of the three concrete cubes at the end of 28 days curing. 
Table 3:- Specimen Properties.

\begin{tabular}{|c|c|c|c|c|c|c|c|c|}
\hline $\begin{array}{l}\text { SR. } \\
\text { No. }\end{array}$ & $\begin{array}{l}\text { Shape of } \\
\text { CFST } \\
\text { Column }\end{array}$ & $\begin{array}{c}\text { Size of } \\
\text { Column }\end{array}$ & Thickness & Length & $\begin{array}{l}\text { Type of } \\
\text { Mild } \\
\text { steel }\end{array}$ & $\begin{array}{l}\text { Type of } \\
\text { Concrete }\end{array}$ & $\begin{array}{l}\text { No of } \\
\text { Specimens }\end{array}$ & Designation \\
\hline \multirow{3}{*}{1} & & \multirow{3}{*}{$114.31 \mathrm{~mm}$ dia } & \multirow{3}{*}{$4.5 \mathrm{~mm}$} & \multirow{3}{*}{$300 \mathrm{~mm}$} & \multirow{3}{*}{ fy3 10} & M20 & \multirow{3}{*}{$3 \times 6=18$} & C01-20toC06-20 \\
\hline & & & & & & M30 & & C07-30toC12-30 \\
\hline & & & & & & M40 & & C13-40toC18-40 \\
\hline \multirow{3}{*}{2} & & \multirow{3}{*}{$91.5 * 91.5 \mathrm{~mm}$} & \multirow{3}{*}{$4.5 \mathrm{~mm}$} & \multirow{3}{*}{$300 \mathrm{~mm}$} & \multirow{3}{*}{ fy 310} & M20 & \multirow{3}{*}{$3 \times 6=18$} & S01-20toS06-20 \\
\hline & & & & & & M30 & & S07-30toS12-30 \\
\hline & & & & & & M40 & & S13-40toS18-40 \\
\hline
\end{tabular}

\section{Experimental Results:-}

Axial shortening curves (compressive load vs vertical deformations) for the square and circular CFST columns are shown in Chart-1 to 5.

All the square and circular CFST columns have not definite axial shortening during the initial linear stage during loading process, which shows the composite action between steel tube and the concrete core.

The strengths are compared according to different grades of concrete used. According to the results higher strength concrete has more load bearing capacity at low deformation. So, the axial load capacity is gradually increased for both of the square \& circular CFST columns when the grade of concrete is increased from M20 to M30 \& M40. Square columns have more load bearing capacity then circular columns.

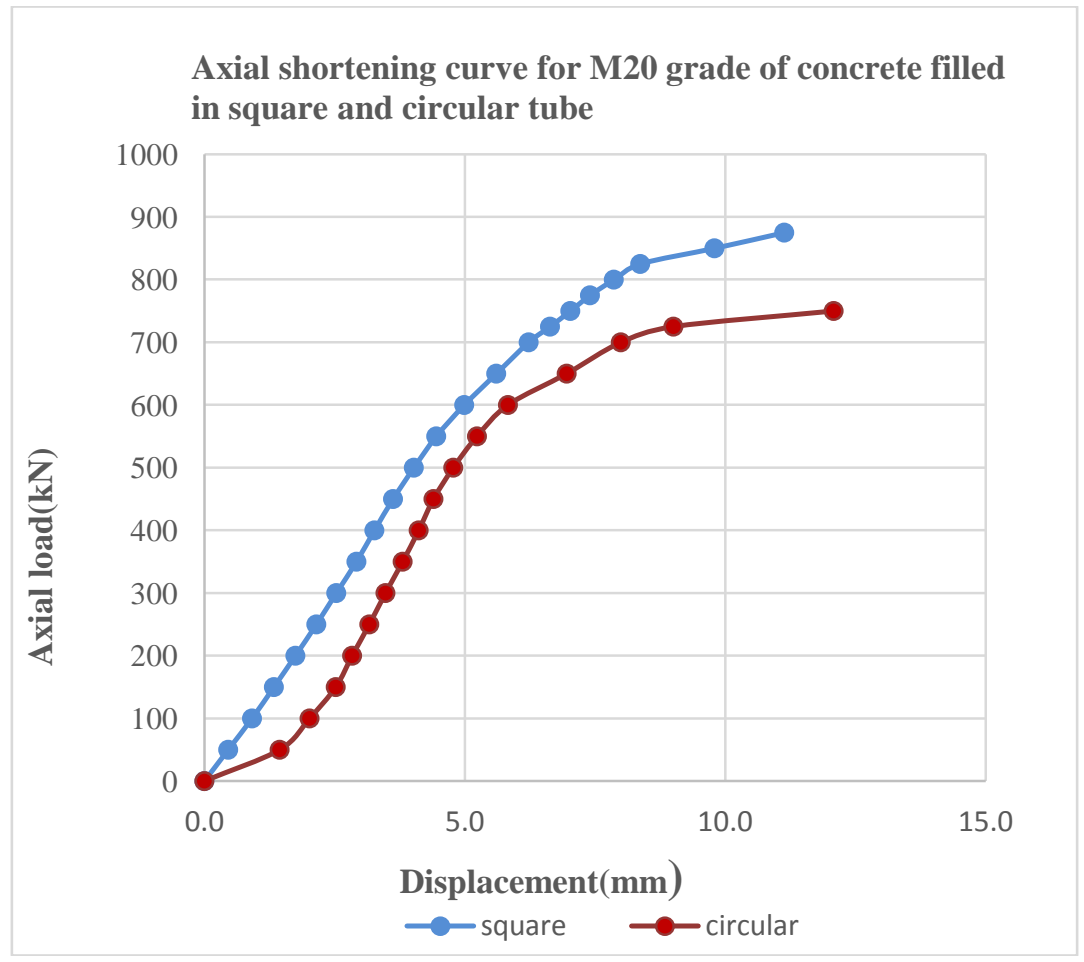

Chart: 1:- 


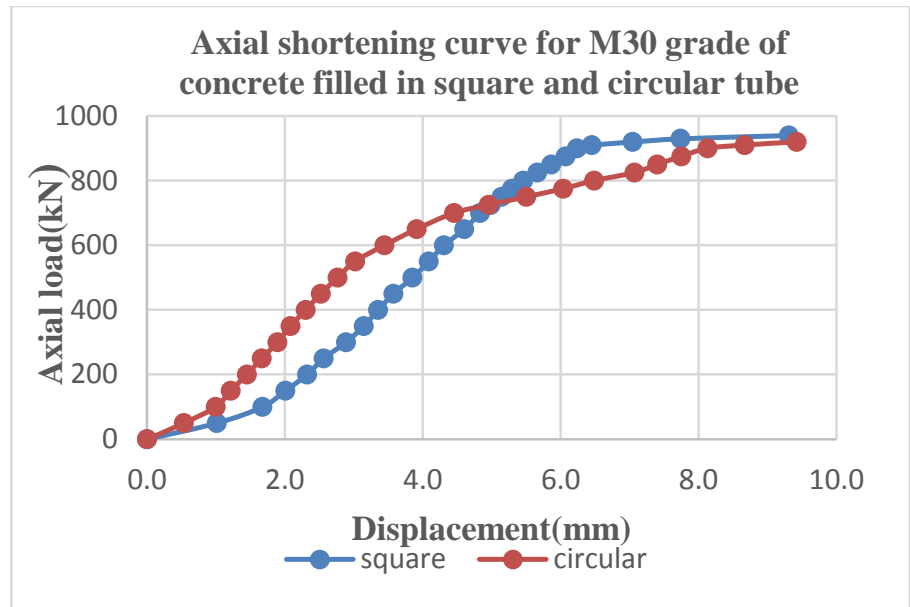

Chart: 2:-

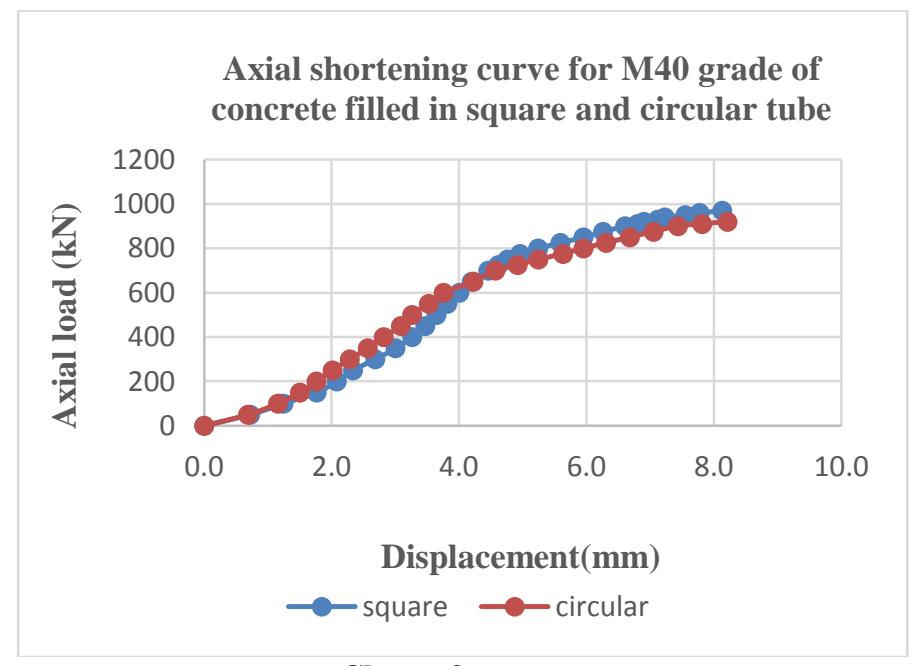

Chart: 3:-

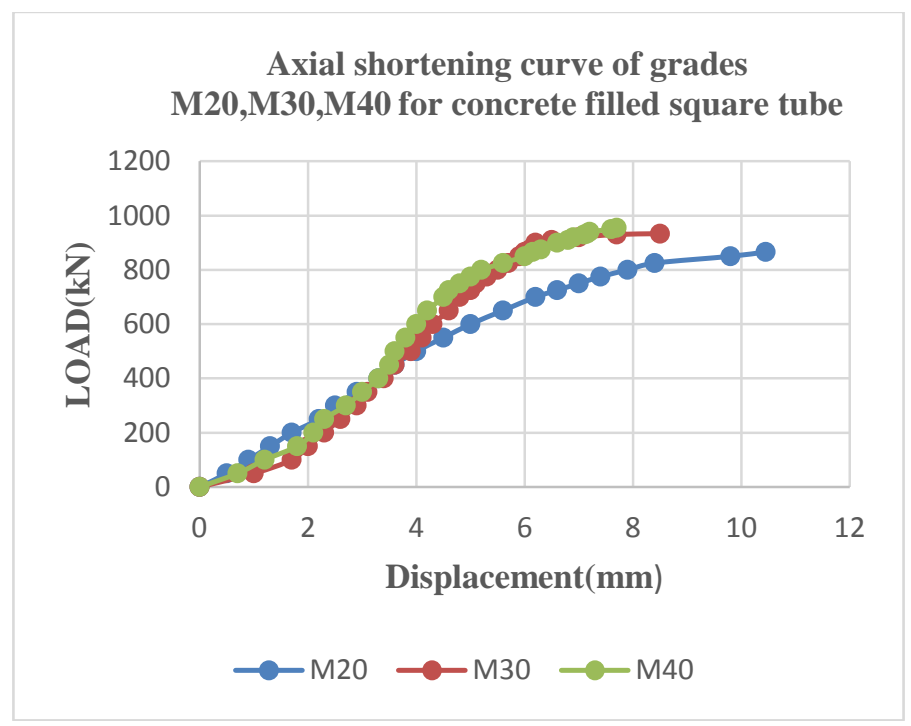

Chart 4:- 


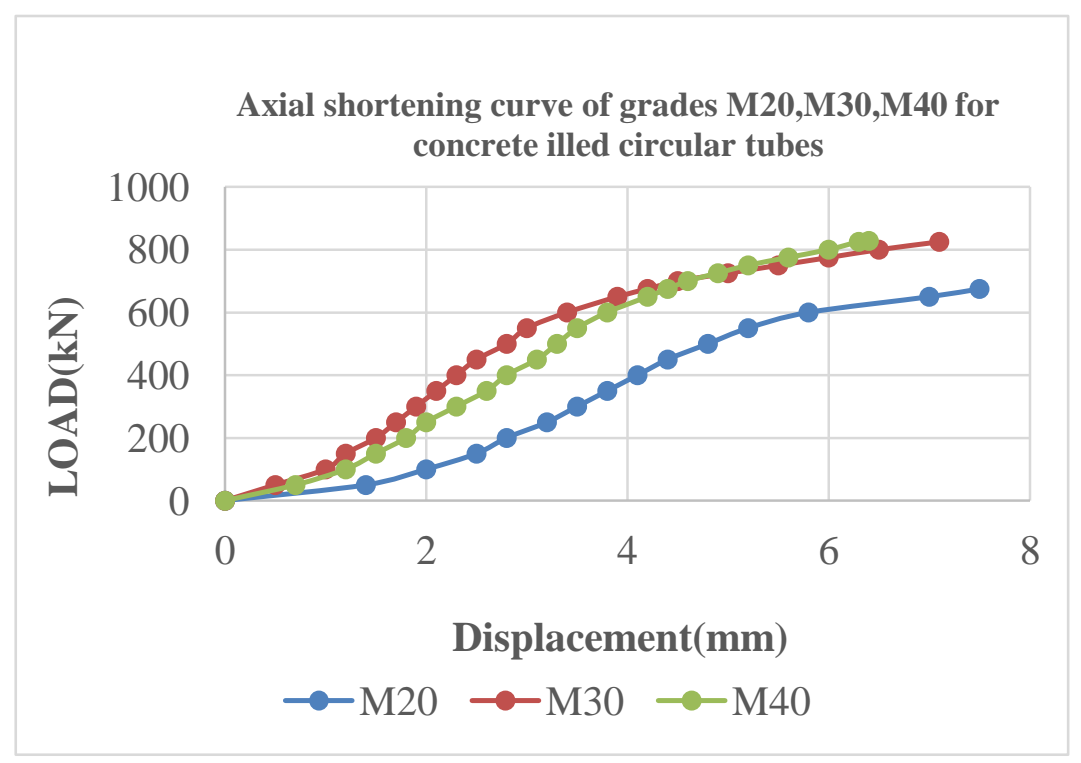

Chart 5:-

Table 4:- Square and Circular CFST Test Results

\begin{tabular}{|c|c|c|c|c|c|c|c|c|c|}
\hline $\begin{array}{l}\text { Square } \\
\text { specimen }\end{array}$ & $\mathrm{Fck}\left(\mathrm{N} / \mathrm{mm}^{\wedge} 2\right)$ & $\begin{array}{l}\text { Load(Pue) } \\
\text { (kN) }\end{array}$ & $\begin{array}{c}\text { Avg.Pue } \\
\text { (kN) }\end{array}$ & $\begin{array}{l}\text { Avg.Pue }(\mathrm{KN}) * 0.9 \\
\text { (calibration factor) }\end{array}$ & $\begin{array}{l}\text { Circular } \\
\text { specimen }\end{array}$ & $\operatorname{Fck}\left(\mathrm{N} / \mathrm{mm}^{\wedge} 2\right)$ & $\begin{array}{c}\text { Load(Pue) } \\
\text { (kN) }\end{array}$ & $\begin{array}{l}\text { Avg.Pue } \\
\text { (kN) }\end{array}$ & $\begin{array}{l}\text { Avg.Pue(KN)*0.9 } \\
\text { (calibration factor) }\end{array}$ \\
\hline S01-20 & \multirow{6}{*}{20} & 825 & \multirow{6}{*}{866.67} & \multirow{6}{*}{780.00} & $\mathrm{C} 01-20$ & \multirow{6}{*}{20} & 750 & \multirow{6}{*}{750} & \multirow{6}{*}{675} \\
\hline SO2-20 & & 875 & & & $\mathrm{CO}-20$ & & 750 & & \\
\hline S03-20 & & 875 & & & C03-20 & & 750 & & \\
\hline SO4-20 & & 875 & & & $\mathrm{CO}-20$ & & 750 & & \\
\hline S05-20 & & 875 & & & C05-20 & & 750 & & \\
\hline S06-20 & & 875 & & & $\mathrm{CO6}-20$ & & 750 & & \\
\hline $507-30$ & \multirow{6}{*}{30} & 910 & \multirow{6}{*}{933} & \multirow{6}{*}{840} & $\mathrm{C} 07-30$ & \multirow{6}{*}{30} & 910 & \multirow{6}{*}{916.67} & \multirow{6}{*}{825} \\
\hline S08-30 & & 940 & & & C08-30 & & 920 & & \\
\hline S09-30 & & 940 & & & Co9-30 & & 920 & & \\
\hline $\mathrm{S} 10-30$ & & 940 & & & $\mathrm{C} 10-30$ & & 910 & & \\
\hline S11-30 & & 940 & & & C11-30 & & 920 & & \\
\hline $\mathrm{S} 12-30$ & & 930 & & & C12-30 & & 920 & & \\
\hline $\mathrm{S} 13-40$ & \multirow{6}{*}{40} & 970 & \multirow{6}{*}{955} & \multirow{6}{*}{859.5} & $\mathrm{C} 13-40$ & \multirow{6}{*}{40} & 920 & \multirow{6}{*}{920} & \multirow{6}{*}{828} \\
\hline S14-40 & & 950 & & & C14-40 & & 920 & & \\
\hline S15-40 & & 970 & & & C15-40 & & 920 & & \\
\hline S16-40 & & 970 & & & C16-40 & & 920 & & \\
\hline S17-40 & & 970 & & & C17-40 & & 920 & & \\
\hline S18-40 & & 900 & & & C18-40 & & 920 & & \\
\hline
\end{tabular}

\section{Conclusions}

$>$ The percentage increase in ultimate load of M20, M30 and M40 grade of concrete filled square column to circular column is about $15 \%, 2 \%$, and $4 \%$ respectively.

$>$ Ultimate load of Square CFST Columns is higher than circular ones. Load bearing capacity increases with the higher grade of concrete.

$>$ For Concrete filled Square tube Columns, Deformation is decreased by $10 \%$ to $25 \%$ by increasing the Grades of concrete.

$>$ For Concrete filled Circular Columns, Deformation is decreased by $5 \%$ to $11 \%$ by increasing the Grades of concrete. 


\section{References:-}

1. Theoretical Investigations on Design Approaches of Concrete Filled Steel Tubular Columns by Sankar Jegadesh J .S. and S. Jayalekshmi Research Scholar ISBN: 978- 81- 929742- 0- 0. pp.122 to 126.

2. BurakEvirgen, KivancTaskin, 2014 Structural behavior of concrete filled steel tubular Sections (CFT/CFST) under axial compression, research article in thin walled structures.

3. Circular Concrete-Filled Tubular Columns: State of the Art Oriented to the Vulnerability Assessment. By Rolando Chacon, From The Open Civil Engineering Journal,Vol - 9, (Suppl. 1, M 4) pp. 249-259,2015.

4. Performance of Concrete Filled Steel Tube (CFST) Section: Review from International Journal of Science and Research (IJSR) ISSN (Online): 2319-7064 Index Copernicus Value (2013): 6.14 | Impact Factor (2014): 5.611 By, Vishal V. Gore and Popat D. Kumbhar. Vol. - 4, pp. - 645-647.

5. Eurocode4.Design of composite steel and concrete structures. Part1.1, General rules and rules for buildings (with UK national application document), DDENV1994-1-1.London (UK): British Standards Institution; 1994.

6. IS 456 - 2000 Plain and Reinforced Concrete Code of practice, Bureau of Indian Standards, New Delhi, 2000.

7. R. P. Johnson, Composite structure of steel and concrete, Vol.1, Blackwell Scientific Publications, U.K, 1994.

8. IS: 800, Code of practice for general construction in steel, Bureau of Indian Standards, New Delhi, 2007.

9. IS: 11384, Code of practice for composite construction of steel and concrete, Bureau of Indian Standards, New Delhi, 1985. 